\title{
Efektifitas Peer Education Method Dalam Pencegahan HIV/AIDS Terhadap Pengetahuan Dan Sikap Remaja
}

\author{
Sri Sumartini $^{*}$, Vinna Maretha ${ }^{2}$ \\ ${ }^{1}$ Prodi D3 Keperawatan, FPOK, Universitas Pendidikan Indonesia, Bandung, Indonesia \\ ${ }^{2}$ Keperawatan, STIKes Yayasan Pendidikan Imam Bonjol, Majalengka, Indonesia \\ *email korespondensi: srisumartini@upi.edu
}

\section{ARTICLE INFO \\ HOW TO CITED: \\ Sumartini, S \& Maretha, V (2020). Efektifitas Peer Education Method dalam Pence-gahan HIV/AIDS ter- hadap Pengetahuan dan Sikap Remaja. Jurnal Pendidikan Keperawatan Indonesia. 6(1), p. $77-84$ \\ DOI:}

10.17509/jpki.v6i1.21130

\section{ARTICLE HISTORY:}

Received

November 18, 2019

Revised

April 7, 2020

Accepted

June 07, 2020

Published

June 20, 2020

\begin{abstract}
ABSTRAK
Peer Education merupakan metode Implementasi dan evaluasi program pendidikan sebaya, hal ini juga sebagai upaya Instansi Pendidikan Menengah Atas dalam pencegahan terjadinya perilaku seksual berisiko tinggi (bebas) pada remaja. Program ini bertujuan agar kelompok remaja mendapatkan informasi yang sesuai tentang HIV/AIDS, mampu berdiskusi, memperbaiki sikap dan membentuk norma-norma yang tepat bagi kelompok sebaya, dan mendukung perkembangan seksual tahap remaja. Pendekatan pendidikan sebaya (peer education) sangat efektif sehingga komunikasi lebih mudah sehingga mampu mengubah sikap pada remaja untuk membantu upaya mencegah penyebaran HIV/AIDS. Penelitian yang telah dilaksanakan bertujuan untuk mengetahui efektifitas peer education method dalam pencegahan HIV/AIDS terhadap pengetahuan dan sikap remaja. Metoda Penelitian menggunakan pre-experiment design melalui desain one shot case study. Populasi dalam penelitian merupakan siswa kelas X dan XI di SMA Negeri 1 Majalengka Kabupaten Majalengka sejumlah 691 siswa tekhnik pengambilan sampel adalah simple random sampling jumlah sampel yang didapatkan 88 orang responden. Instrument penelitian menggunakan kuesioner yang telah dilakukan uji validitas kemudian uji reliabilitas. Uji Statistik menggunakan Uji-T, Sehingga mendapatkan Hasil penelitian yaitu pengetahuan remaja pretest sebagian besar responden memiliki pengetahuan cukup dan postest sebagian besar responden pengetahuan tentang HIV/AIDS baik. Sikap remaja pada saat pretest sebagian besar memiliki sikap negatif dan postest sebagian besar memiliki sikap positif. Terdapat effektifitas peer education method dalam mencegah HIV/AIDS terhadap pengetahuan dan sikap remaja. Peer Education method merupakan suatu metode alternatif untuk menilai pengetahuan serta sikap remaja dalam Pencegahan penularan HIV/AIDS.
\end{abstract}

Kata Kunci: Peer Education Method, Pengetahuan, Sikap, HIV/AIDS

\section{ABSTRACT}

Peer Education is a method of implementing and evaluating peer education programs, it is also an effort of senior secondary education institutions in preventing the occurrence of high-risk (free sexual) behavior in adolescents. The program aims to provide youth with appropriate information about HIV/AIDS, be able to discuss, improve attitudes and form appropriate norms for peer groups, and support adolescent stage sexual development. The peer education approach is very effective so that communication is easier so that it can change attitudes towards adolescents to help prevent the spread of HIV/AIDS. The research that has been carried out aims to determine the effectiveness of peer education methods in the prevention of HIV / AIDS on the knowledge and attitudes of adolescents. The research method uses preexperiment design through one shot case study design. The population in this study 
were students of class X and XI in SMA Negeri 1 Majalengka, Majalengka Regency with a total of 691 sampling techniques students were simple random sampling, the number of samples obtained by 88 respondents. The research instrument used a questionnaire that had been tested for validity and then reliability testing. The statistical test uses the T-Test, so that the research results are that the knowledge of pretest teenagers most of the respondents have sufficient knowledge and the posttest of most respondents knowledge of HIV/AIDS is good. Adolescent attitudes at the time of the pretest mostly have negative attitudes and most posttests have positive attitudes. There is an effectiveness of peer education methods in preventing HIV/AIDS against adolescent knowledge and attitudes. The Peer Education method is an alternative method to assess the knowledge and attitudes of adolescents in the prevention of HIV/AIDS transmission.

Keywords: Peer Education method, Knowledge, Attitude, HIV/AIDS

\section{PENDAHULUAN}

Pembangunan Kesehatan adalah sebuah model upaya pemerintah yang berperan untuk meningkatkan Paradigma sehat, cara pandang, pola pikir yang bersifat holistik (Salman Alfarisy et al., 2016) . Cara Pandang Remaja mulai mampu berpikir secara abstrak dan mampu memberi alasan secara rasional. Remaja pun mulai mampu memahami konsep-konsep, mengerti sebab-akibat dari masalah, dapat berdebat atas berbagai sudut pandang dan berespon secara baik untuk berbagai langkah hasil pemikiran dari objek yang dilihat atau menjadi pengalaman (Andrews, 2010).

Program preventif dipengaruhi oleh "pergeseran paradigma" saat ini (Laras, 2016). dalam promosi kesehatan. Program peer education melibatkan pendekatan pendidikan kesehatan tradisional menuju pendekatan pengembangan masyarakat yang melibatkan partisipasi masyarakat lokal dalam intervensi promosi kesehatan seksual dan pencegahan penularan penyakit seksual (Beeker et al., 1998). Pousette et al., 2014 mengatakan pola perilaku seksual berisiko tinggi, pengetahuan yang tidak memadai, dan kesalahpahaman besar terkait dengan HIV/AIDS. Penularan HIV/AIDS rentan terjadi pada siswa universitas dan siswa sekolah menengah atas (usia remaja menuju dewasa awal) (Ibrahim et al., 2012). Menjadikan orang selalu tetap dalam kondisi sehat merupakan upaya peningkatan, pemeliharaan dan perlindungan kesehatan, bukan hanya penyembuhan orang sakit atau pemulihan kesehatan (Kemenkes RI, 2018).

Selama ini, aspek pencegahan menjadi referensi utama, masalah kesehatan lebih menekankan pada penyakit, obat, Puskesmas, Rumah Sakit dan Klinik Dokter, sehingga ketika terjadi masalah kesehatan sangat jarang terpikirkan oleh masyarakat secara umumnya agar penyakit itu tidak terjadi (Laras, 2016). Padahal, masalah kesehatan (penyakit) dapat dicegah dengan upaya preventif hal tersebut dapat dilihat dari hasil penelitian lebih dari 50\% tingkat keberhasilannya (Ibrahim et al., 2012).

Acquired Immunodefiency Syndrome (AIDS) merupakan penurunan system kekebalan tubuh gejala yang timbul diawali dengan perubahan metabolisme pada tubuh (Amalia et al., 2018), HIV/AIDS merupakan salah satu penyakit yang memerlukan upaya-upaya preventif di seluruh dunia, karena penanganan HIV/AIDS terutama di negara-negara berkembang serta pada kawasan berisiko tinggi masih berfokus pada aspek kuratif dan rehabilitatif. Dalam masalah penyebaran HIV/AIDS peran pemerintah Indonesia dan Organisasi dunia telah melaksanakan penanganan tersebut bersifat preventif, promotif, kuratif dan rehabilitatif (Salaswati, 2013). Pemerintah Indonesia, telah menetapkan beberapa kebijakan dan program penanggulangan penyebaran (pencegahan) penularan HIV/AIDS. Komitmen serius telah disusun oleh Pemeritah untuk meningkatkan surveilans seperti menambah fasilitas perawatan, memberikan dukungan, dan pengobatan (Campbell \& Mzaidume, 2001). Upaya berikutnya adalah melalui konseling dan pendidikan kesehatan serta pemberdayaan masyarakat dalam pencegahan HIV/AIDS (Kemenkes RI, 2019). 
United Nations Programme on HIV/AIDS (UNAIDS) mengungkapkan, orang terjangkit HIV/AIDS lebih dari 5.000, dan merupakan kasus baru sebanyak $42 \%$ dari kasus infeksi HIV di seluruh dunia, hal ini terjadi sebagian besar pada usia 15-24 tahun (masa remaja) dan berusia dibawah 15 tahun meninggal setiap tahunnya sejumlah 1.400 anak karena penyakit yang berkaitan dengan AIDS (UNAIDS, 2011). Jumlah kumulatif dari kasus infeksi HIV yang dilaporkan hingga bulan Juni 2018 adalah 301.959 Jiwa (47\% dari kasus ODHA sebanyak 640.443 Jiwa) dan lebih besar ditemukan pada kelompok umur 2549 tahun (Kemenkes RI, 2019). Angka kejadian HIV di Propinsi Jawa Barat bulan Oktober hingga Desember 2017 di Indonesia menempati urutan keempat tertinggi yaitu sebanyak 1.611 kasus dari 48.300 kasus, sedangkan untuk AIDS menempati urutan kedua yaitu sebanyak 1.186 kasus dari 9.280 kasus yang dilaporkan (Kemenkes RI, 2018). Presentasi berdasarkan kelompok umur infeksi HIV yang dilaporkan bulan OktoberDesember 2017 usia 15-19 tahun sebanyak 4,0\%, 20-24 tahun sebanyak16,7\%, 25-49 tahun sebanyak $69,2 \%$. Angka kejadian AIDS yang dilaporkan usia 15-19 tahun sebanyak 23\%, 20-29 tahun adalah 29,5\%, sedangkan 30-39 tahun adalah 35,2\% dan 40-49 tahun adalah $17,7 \%$ (KemenkesRI, 2018).

Pendidikan kesehatan tentang HIV/AIDS merupakan kebutuhan mendesak di Indonesia (Amalia et al., 2018). Upaya preventif untuk menghambat semakin meningkatnya kasus bahkan dengan memutus angka kejadian dapat dilakukan dengan cara memberikan pendidikan Kesehatan melalui peer education method pada remaja. Usia Remaja merupakan kelompok yang paling rentan terhadap penularan infeksi dan menjadi fokus dari semua strategi penanggulangan penyebaran virus HIV/AIDS (Moore et al., 1995). Menggunakan penyebaran informasi dan pendidikan Kesehatan (Pendkes) tentang HIV/AIDS menggunakan metode peer education method pada remaja sangat efektif dalam meningkatkan pengetahuan serta mempengaruhi sikap remaja berisiko terhadap terjangkitnya oleh virus (Merakou \& Kourea-
Kremastinou, 2006). Pendidikan Kesehatan harus melampaui metode pendidikan tradisional, terutama ketika menyangkut anak muda. Intervensi preventif yang hanya menyediakan informasi tentang HIV / AIDS telah terbukti tidak efektif dalam mengubah perilaku berisiko (Mukuka \& Slonim-Nevo, 2006).

Ketidaktahuan remaja tentang HIV/AIDS adalah kesalahan mendapatkan informasi, selain itu adanya pergeseran nilai dan perilaku, seks bebas (free sexual) dan pemakian narkoba merupakan kejadian yang paling sering terjadi sebagai penyebab penyebaran virus. Maka perlu adanya upaya pencegahan dan perlindungan pada kelompok remaja secara efektif dan komprehensif (Falchikov \& Goldfinch, 2000). Pendidikan sebaya tampaknya menjadi metode yang menjanjikan dalam mempromosikan perilaku pendidikan risiko di kalangan anak muda. Intervensi pendidikan sebaya untuk pencegahan HIV/AIDS biasanya didasarkan pada teori perilaku (Merakou \& Kourea-Kremastinou, 2006). Metoda penyampaian informasi dengan berbagai metode baik secara langsung maupun tidak langsung adalah upaya Program pemberian pendidikan kesehatan dengan metode peer education selama ini telah dilakukan khususnya berkaitan dengan HIV/AIDS (Ibrahim et al., 2012). Metoda informasi secara langsung yaitu melalui metode seminar atau ceramah maupun metode diskusi. Adapun, yang dilakukan komunikasi tidak langsung antara lain menggunakan media elektronik maupun cetak. Meskipun demikian, kasus HIV/AIDS pada remaja masih tetap terjadi dan cenderung meningkat (Kasih, 2016).

Salah satu pendekatan yang efektif program pendidikan kesehatan pada remaja untuk mencegah maraknya kasus HIV/AIDS yaitu dengan metode Peer Education (pendidikan sebaya), melalui metoda tersebut diharapkan terbinanya kelompok-kelompok motivator remaja dalam penanggulangan penyebaran HIV/ AIDS (Andrews, 2010). Pendidikan sebaya telah banyak dianjurkan sebagai alternatif atau pelengkap intervensi yang disajikan oleh orang dewasa dan menjadi metode yang semakin populer untuk 
mempromosikan perubahan perilaku dalam program pencegahan HIV (UNAIDS, 2011), (Visser, 2007). Pendekatan secara kolektif sangat bermakna, komunikasi menjadi lebih lancar dan mampu membuat perubahan sikap dikalangan remaja. Tabunya pendidikan seks dikalangan tertentu dalam hal ini adalah remaja, membutuhkan Komunikasi, Informasi serta Edukasi (KIE) yang benar, tepat (Hasbi, 2019). penyampaian informasi melalui metoda pendidikan sebaya (peer education method) secara berkesinambungan pada kalangan remaja sebagai upaya pemberian informasi tentang Kesehatan reproduksi dan Penyakit Menular Seksual yang integral dalam penanggulangan dan pencegahan HIV/AIDS (Menna et al., 2015). Para remaja dapat mengembangkan pesan maupun memilih media yang lebih kreatif sehingga informasi yang diterima dapat dimengerti oleh sesama mereka melalui peer education method. Kelebihan metode ini salah satunya yaitu kebebasan remaja untuk mengemukakan pendapatnya (Kasih, 2016).

Ketidaktahuan remaja diketahui setelah dilakukan observasi sikap dan wawancara terhadap 20 orang remaja siswa dan siswi di Sekolah Menengah Atas (SMA) dengan rentang usia 15-18 tahun, diketahui sebanyak 14 orang (70\%) belum mengetahui mengenai penularan serta dampak HIV/AIDS dengan tepat dan 12 orang $(60 \%)$ menyatakan bahwa memiliki kekasih berdasarkan cinta kasih merupakan suatu yang wajar, sehingga hal tersebut menunjukkan bahwa masih perlu adanya upaya pencegahan dengan menambah pengetahuan dan mengubah sikap remaja tentang pencegahan penularan HIV/AIDS melalui pendekatan peer learning method.

\section{METODE PENELITIAN}

Penelitian menggunakan desain penelitian dengan pre-experiment design. Dengan jenis One Shot Case Study design, dimana desain ini tanpa adanya kelompok pembanding (control group), sebelumnya telah dilakukan pengukuran awal (pretest) yang memungkinkan penelitian dapat menguji perubahan-perubahan yang terjadi setelah adanya eksperimen (program). Penelitian metode pre-experiment design dengan desain one-shot case study dalam hal ini penelitian pre eksperimen yang dilakukan dengan memberikan perlakuan pada kelompok studi dan selanjutnya di observasi efeknya. Peneliti dalam melakukan penelitian tidak melakukan randomisasi tetapi dengan menetapkan kelompok studi. Desain tersebut dapat dilihat pada bagan berikut:

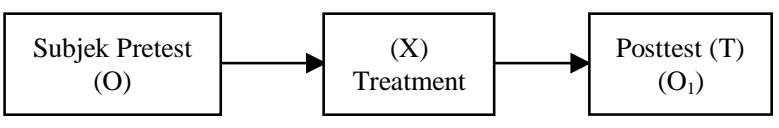

Gambar 1. Desain Penelitian Efektifitas Peer Education Method dalam Pencegahan HIV/AIDS

Lokasi penelitian dilaksanakan di Sekolah Menengah Atas Negeri 1 Majalengka, keberadaannya di pusat Kota Majalengka, dan juga sebagai sekolah favorit, dinilai dari kelengkapan fasilitasnya cukup baik dan memiliki kelas yang international standard sehingga menjadi pilihan utama peneliti sebagai tempat penelitian. Berdasarkan data jumlah populasi sebanyak 691 siswa yang terdiri dari kelas X sebanyak 359 orang, dan kelas XI sebanyak 332 orang. Simple random sampling tekhnik yang digunakan dalam pengambilan sampel, siswa yang dijadikan sampel, diambil dengan teknik pengambilan secara acak (random). Teknik ini dipakai karena populasi dalam penelitian ini bersifat homogen. Sehingga, didapatkan sampel penelitian sejumlah 88 responden. Teknik pengambilan data, sebelum dilakukan kegiatan peer education diambil 8 orang untuk dilakukan persamaan persepsi pengetahuan tentang pencegahan HIV/AIDS, dan selanjutnya dibagi menjadi 10 peer groups. Remaja siswa diberikan kuesioner sebagai instrument penelitian, oleh peneliti ambil data pengetahuan dan sikap dari para remaja yang mengikuti peer education method.

\section{HASIL}

Penelitian yang didapatkan peer education method dalam menanggulangi HIV/AIDS disajikan dalam bentuk tabel dan narasi. Hasil pengukuran melalui tahapan analisis univariat selanjutnya dilakukan analisis bivariat. 


\section{Analisis Univariat}

Gambaran pengetahuan responden diketahui pada analisis univariat, dan hasilnya dapat dilihat pada tabel sebagai berikut:

Tabel 1. Pengetahuan Remaja dalam Mencegah HIV/AIDS Pre-Peer Education Method

\begin{tabular}{lcc}
\hline $\begin{array}{c}\text { Pengetahuan Remaja Pre- } \\
\text { Peer Education (Pretest) }\end{array}$ & $\begin{array}{c}\text { Frekuensi } \\
(\mathbf{f})\end{array}$ & $\begin{array}{c}\text { Persentase } \\
(\mathbf{\%})\end{array}$ \\
\hline Baik & 16 & 18.2 \\
Cukup & 55 & 62.5 \\
Kurang & 17 & 19.3 \\
\hline Jumlah & $\mathbf{8 8}$ & $\mathbf{1 0 0 . 0}$ \\
\hline
\end{tabular}

Informasi yang didapatkan pada Tabel 1 diketahui bahwa lebih dari setengah remaja mengikuti pre test berpengetahuan cukup tentang pencegahan HIV/AIDS yaitu sejumlah 55 responden $(62,5 \%)$ dari 88 responden. Namun hasil post test peer education method, pengetahuan remaja dapat dilihat pada table sebagai berikut:

Tabel 2. Pengetahuan Remaja dalam Mencegah HIV/AIDS Post-Peer Education Method

\begin{tabular}{lcc}
\hline $\begin{array}{c}\text { Pengetahuan Remaja Post- } \\
\text { Peer Education (Postest) }\end{array}$ & $\begin{array}{c}\text { Frekuensi } \\
(\mathbf{f})\end{array}$ & $\begin{array}{c}\text { Persentase } \\
(\boldsymbol{\%})\end{array}$ \\
\hline Baik & 49 & 55.7 \\
Cukup & 39 & 44.3 \\
Kurang & 0 & 0 \\
\hline Jumlah & $\mathbf{8 8}$ & $\mathbf{1 0 0 . 0}$ \\
\hline
\end{tabular}

Informasi yang didapatkan pada Tabel 2 diketahui bahwa lebih dari setengah remaja posttest Peer Education Method

Memiliki pengetahuan yang baik tentang penanggulangan HIV/AIDS yaitu sejumlah 49 responden $(55,7 \%)$ dari 88 responden.

Tabel 3. Sikap Remaja Pre-Peer Education (Pre test) dalam Mencegah HIV/AIDS

\begin{tabular}{lcc}
\hline $\begin{array}{c}\text { Sikap Remaja Pre-Peer } \\
\text { Education (Pretest) }\end{array}$ & $\begin{array}{c}\text { Frekuensi } \\
\text { (f) }\end{array}$ & $\begin{array}{c}\text { Persentase } \\
(\mathbf{\%})\end{array}$ \\
\hline Negatif & 49 & 55.7 \\
Positif & 39 & 44.3 \\
\hline Jumlah & $\mathbf{8 8}$ & $\mathbf{1 0 0 . 0}$ \\
\hline
\end{tabular}

Informasi yang didapatkan pada Tabel 3 diketahui bahwa lebih dari setengah remaja Pre Test Peer Education bersikap negatif terhadap penanggulangan HIV/AIDS yaitu sebanyak 49 responden $(55,7 \%)$ dari 88 responden.

Tabel 4. Sikap Remaja Post-Peer Education (Post test) dalam Mencegah HIV AIDS

\begin{tabular}{lcc}
\hline $\begin{array}{c}\text { Sikap Remaja Post-Peer } \\
\text { Education (Postest) }\end{array}$ & $\begin{array}{c}\text { Frekuensi } \\
\text { (f) }\end{array}$ & $\begin{array}{c}\text { Persentase } \\
(\boldsymbol{\%})\end{array}$ \\
\hline Negatif & 40 & 45.5 \\
Positif & 48 & 54.5 \\
\hline Jumlah & 88 & 100.0 \\
\hline
\end{tabular}

Informasi yang didapatkan pada Tabel 4 diketahui bahwa lebih dari setengah remaja Post Test Peer Education bersikap positif terhadap penanggulangan HIV/AIDS yaitu sebanyak 48 responden $(54,5 \%)$ dari 88 responden.

\section{Analisis Bivariat}

Analisis Bivariat dapat dilihat dalam tabel sebagai berikut:

Tabel 5. Efektifitas Peer Education Method dalam Pencegahan HIV/AIDS terhadap Pengetahuan Remaja

\begin{tabular}{|c|c|c|c|c|c|c|}
\hline Variabel & Mean & $\mathbf{N}$ & $\begin{array}{l}\text { Beda } \\
\text { Mean }\end{array}$ & SD & $\mathbf{T}$ & ovalue \\
\hline $\begin{array}{l}\text { Pengetahuan } \\
\text { (Pre test) }\end{array}$ & 18.53 & 88 & \multirow[b]{2}{*}{3,30} & 3.089 & \multirow[b]{2}{*}{11,710} & \multirow[b]{2}{*}{0,000} \\
\hline $\begin{array}{l}\text { Pengetahuan } \\
\text { (Post test) }\end{array}$ & 21.83 & 88 & & 2,408 & & \\
\hline
\end{tabular}

Menurut hasil penghitungan statistik dengan paired sample t-test diperoleh $\mathrm{t}$-value $=11,710$ dan $\rho$ value $=0,000$ yang berarti $\rho$ value $<\alpha$, sehingga hipotesis nol ditolak. Dengan demikian terdapat efektifitas peer education method dalam pencegahan HIV/AIDS terhadap pengetahuan remaja.

Tabel 6. Efektifitas Peer Education Method dalam Pencegahan HIV/AIDS terhadap Sikap Remaja

\begin{tabular}{|c|c|c|c|c|c|c|}
\hline Variabel & Mean & $\mathbf{N}$ & $\begin{array}{l}\text { Beda } \\
\text { Mean }\end{array}$ & SD & $\mathbf{T}$ & ovalue \\
\hline Sikap (Pretest) & 24.23 & 88 & & 2.599 & 13,001 & \\
\hline Sikap (Postest) & 28.70 & 88 & $4.4 /$ & 3.572 & 15,001 & 0,000 \\
\hline
\end{tabular}

Menurut hasil penghitungan menggunakan paired sample t-test diperoleh $\mathrm{t}$-value $=13,001$ dan $\rho$ value $=0,000$ yang berarti $\rho$ value $<\alpha$, sehingga 
hipotesis nol ditolak. Maka, terdapat efektifitas peer education method dalam pencegahan HIV/AIDS terhadap sikap remaja.

\section{PEMBAHASAN}

Peer education method merupakan metode efektif bagi para peer aducator yang sebelumnya telah mendapatkan penyamaan persepsi dalam menyampaikan informasi secara langsung dan tepat. Dibantu dengan membentuk kelompokkelompok kecil sehingga secara privasi dari anggota kelompok dapat terjamin. Informasi mengenai HIV/AIDS masih dirasakan tabu bagi para remaja.

Hasil penelitian menunjukkan bahwa terdapat efektifitas peer education method dalam pencegahan HIV/AIDS terhadap pengetahuan remaja ( $\rho$ value $=0,000)$. Sejalan dengan Santoso et al., 2010 yaitu melalui pendidikan kesehatan kesenjangan antara informasi dan tingkah laku kesehatan dapat dipengaruhi dengan adanya pendidikan Kesehatan, memotivasi seseorang untuk menerima informasi kesehatan dan berperilaku positif agar mereka menjadi lebih tahu dan lebih sehat.

Peer education method selain efektif juga pendekatan pendidikan kesehatan yang efisien pada remaja untuk mencegah meningkatnya kasus HIV/AIDS (Salman Alfarisy et al., 2016). Pendidikan kelompok sebaya dilaksanakan antar kelompok sebaya tersebut dengan dipandu oleh peer educator yang juga berasal dari kelompok itu sendiri yang telah mendapatkan persamaan persepsi mengenai materi pencegahan penyebaran HIV/AIDS pada remaja akibat perilaku sesksual menyimpang (seks bebas). Melalui pendidikan sebaya kaum muda, dapat mengembangkan pesan maupun memilih media yang lebih tepat sehingga informasi yang diterima dapat dimengerti oleh sesama mereka (Salaswati, 2013). Pendidikan sebaya tersebut seorang peer educator harus mampu mempengaruhi pengetahuan remaja dalam kelompoknya. Saat mendiskusikan tentang HIV/AIDS tidak terlepas dari perilaku menyimpang seperti masalah seks bebas dan ketergantungan Narkoba, pada kelompok usia remaja ini membicarakan tentang seks masih dianggap malu dan dianggap tabu, namun jika di sampaikan oleh teman sebaya maka responden tidak merasa malu, tidak sungkan dan mau bertanya untuk menambah pengetahuan mereka (Andayani \& Juliandi Harahap, 2017).

Menurut (Laras, 2016) bahwa pengetahuan merupakan hasil tranfer informasi mengenai banyak hal melalui panca indra. Proses transfer ilmu dalam kegiatan peer education method hal ini menunjukkan bahwa sesuatu yang pernah dialami dapat menjadi suatu hal yang akan diingat dan menjadi suatu pengetahuan bagi seseorang remaja dalam waktu jangka pendek dan merubah sikap seseorang menjadi lebih positif (Salman Alfarisy et al., 2016).

Peer education method merubah remaja menjadi lebih berprinsip, dari tidak tahu menjadi lebih tahu yang sebelumnya informasi tersebut terasa tabu (Santoso et al., 2010). Metode tersebut mampu memberikan keyakinan pada remaja bahwa pengetahuan tidak memiliki batas untuk diketahui dan difahami. Menurut Visser, 2007 bahwa justified true believe dapat meningkat sejalan dengan bertambahnya pengetahuan. Seorang individu membenarkan (justifies) kebenaran atas kepercayaannya berdasarkan observasinya mengenai dunia, maka dari itu pengetahuan merupakan susunan bangunan terdiri dari kenyataan dan sesuatu yang benar secara abstrak. Membentuk pengetahuan, perasaan dan sistem kepercayaan (belief sistems) dimana perasaan atau sistem kepercayaan itu bisa tidak disadari (Visser, 2007).

Penelitian yang telah dilakukan mendapatkan hasil yang menunjukkan terdapat efektifitas peer education method terhadap sikap remaja dalam mencegah penyebaran virus HIV/AIDS $(\rho$ value $=0,000)$. Hope, 2003 mengungkapkan bahwa informasi yang disampaikan melalui pendidikan kesehatan tentang HIV/AIDS dengan menggunakan peer education method terbukti efektif dalam mempengaruhi sikap remaja. Peer education method dapat mengubah sikap remaja secara efektif karena kondisi diskusi yang terbuka di kalangan remaja mendukung 
terhadap komunikasi dengan adanya tanya jawab dan feed back dari peer educator melalui sharing yang lebih luas sehingga wawasan remaja yang awalnya tidak tahu menjadi tahu dan memiliki sikap lebih waspada terhadap penyebaran HIV/AIDS. Metode Pendidikan sebaya (peer education method) biasanya melibatkan peer educator dalam membentuk anggota kelompok untuk memberikan informasi dalam kelompok usia yang sama tanpa ada rasa canggung ataupun malu. Pendidikan sebaya sering digunakan untuk mengubah tingkat perilaku pada individu dengan cara memodifikasi pengetahuan, sikap, keyakinan, atau perilaku seseorang (Salaswati, 2013).

Sikap jika tanpa ada proses yang mendasarinya tidak dapat berubah begitu saja (Menna et al., 2015). Peer education method akan mengubah cara berfikir dan bersikap dari seseorang dengan berdialog atau diskusi secara terbuka dalam mengeluarkan pendapatnya masingmasing. Menurut Ibrahim et al., 2012 bahwa sikap merupakan perbuatan yang didasari oleh keyakinan dan norma-norma yang ada di masyarakat dan diyakini oleh masing-masing individu.

Penelitian Andayani \& Juliandi Harahap, 2017 mengungkapkan bahwa perasaan, pemikiran, pengetahuan, keyakinan dan pengalaman akan membentuk sikap seseorang akan menjadi lebih

\section{DAFTAR PUSTAKA}

Amalia, R., Sumartini, S., \& Sulastri, A. (2018). Gambaran Perubahan Psikososial dan Sistem Pendukung Pada Orang Dengan HIV/AIDS (ODHA) di Rumah Cemara Gegerkalong Bandung. JURNAL PENDIDIKAN KEPERAWATAN INDONESIA. https:// doi.org/10.17509/jpki.v4i1.12346

Andayani, L. S., \& Juliandi Harahap. (2017). Pengaruh Peer Education terhadap Pengetahuan dan Sikap Mahasiswa Universitas Sumatera Utara dalHIV/AIDS. Semanticscholar, 161-166.

Andrews, L. (2010). Hindari AIDS Demi Masa Depan Kita Semua. MONORA.

Beeker, C., Guenther-Grey, C., \& Raj, A. (1998). Community empowerment paradigm drift and baik karena dibekali dengan pengetahuan yang baik. Özcebe et al., 2004 menyatakan untuk membangun sikap dan nilai positif di kalangan remaja dalam menanggulangi HIV/AIDS perlu adanya sautu metode yang efektif dan salah satunya dapat menggunakan peer education method, karena diskusi di kalangan remaja dan oleh remaja lebih tebuka serta akan menghasilkan komunikasi yang aktif di kalangan remaja. Sikap yang didasari oleh pengetahuan akan menghasilkan tindakan yang dapat bersifat langgeng. Peer educator sebagai pemberi informasi mampu mempengaruhi teman sebayanya, untuk melihat secara positif mengenai masalah-masalah yang terjadi pada penyakit HIV/AIDS (Visser, 2007).

\section{KESIMPULAN}

Peer education merupakan salah satu Langkah alternatif untuk meningkatkan pengetahuan dan sikap remaja dalam pencegahan penularan HIV/AIDS. Program intervensi perilaku oleh peer educator lebih efektif untuk meningkatkan pengetahuan dan sikap, untuk membangun nilai positif dikalangan remaja dalam pencegahan infeksi HIV/AIDS. Asumsi peneliti terdapat efektifitas peer education method dalam pencegahan HIV/AIDS baik dari segi pengetahuan serta sikap remaja.

the primary prevention of HIV/AIDS. Social Science and Medicine. https://doi.org/ 10.1016/S0277-9536(97)00208-6

Campbell, C., \& Mzaidume, Z. (2001). Grassroots participation, peer education, and HIV prevention by sex workers in South Africa. American Journal of Public Health, 91(12), 1978-1986. https://doi.org/10.2105/AJPH.91. 12.1978

Falchikov, N., \& Goldfinch, J. (2000). Student peer assessment in higher education: A metaanalysis comparing peer and teacher marks. Review of Educational Research. https:// doi.org/10.3102/00346543070003287

Hasbi, M. (2019). ANALISIS MODEL PEER EDUCATION METODE ADOLESCENT FRIENDLY TERHADAP PENINGKATAN 
PENGETAHUAN DAN SIKAP REMAJA TENTANG PERILAKU SEKSUAL BERISIKO (Vol. 1, Issue 1). April. http://jkt.poltekkesmataram.ac.id/index.php/home/index

Hope, K. R. (2003). Promoting Behavior Change in Botswana: An Assessment of the Peer Education HIV/AIDS Prevention Program at the Workplace. Journal of Health Communication, 8(3), 267-281. https:// doi.org/10.1080/10810730305685

Ibrahim, N., Rampal, L., Jamil, Z., \& Zain, A. M. (2012). Effectiveness of peer-led education on knowledge, attitude and risk behavior practices related to HIV among students at a Malaysian public university - A randomized controlled trial. Preventive Medicine, 55(5), 505-510. https://doi.org/10.1016/j.ypmed. 2012.09.003

Kasih, L. C. (2016). Efektifitas Peer Education Pada Pengetahuan Dan Sikap Siswa SMA Dalam Pencegahan HIV/AIDS. Jurnal Ilmu Keperawatan, 4(2), 26-33.

KemenkesRI. (2018). Laporan_HIV_AIDS_TW_ 4_Tahun_2017_1_.pdf.

KemenkesRI. (2019). Lembaran Negara, Perundang-undangan, Pembentukan Peraturan Rahmat, Dengan Yang, Tuhan Esa, Maha Indonesia, Presiden Republik (Issue 183).

Laras, C. (2016). Efektifitas Peer Education Pada Pengetahuan Dan Sikap Siswa SMA Dalam Pencegahan HIV/AIDS. Jurnal Ilmu Keperawatan. jurnal.unsyiah.ac.id

Menna, T., Ali, A., \& Worku, A. (2015). Effects of peer education intervention on HIV/AIDS related sexual behaviors of secondary school students in Addis Ababa, Ethiopia: A quasiexperimental study. Reproductive Health, 12(1). https://doi.org/10.1186/s12978-0150077-9

Merakou, K., \& Kourea-Kremastinou, J. (2006). Peer education in HIV prevention: An evaluation in schools. European Journal of Public Health, 16(2), 128-132. https:// doi.org/10.1093/eurpub/cki162

Moore, J., Beeker, C., Harrison, J. S., Eng, T. R., \& Doll, L. S. (1995). HIV risk behavior among Peace Corps Volunteers. AIDS. https://doi.org/10.1097/00002030-

199507000-00018
Mukuka, L., \& Slonim-Nevo, V. (2006). AIDSrelated knowledge, attitude, and behavior among adolescents in Zambia. Ethnicity and Disease, 16(2), 488-494. https://doi.org/ 10.1007/s10461-005-3903-1

Özcebe, H., Akin, L., \& Aslan, D. (2004). A peer education example on HIV/AIDS at a high school in Ankara. Turkish Journal of Pediatrics, 46(1), 54-59.

Pousette, A., Larsman, P., Hemlin, S., Kauth, M. R., Sullivan, G., Blevins, D., Cully, J. A., Landes, R. D., Said, Q., Teasdale, T. A., Boasberg, J., The Department of Education, Academy, T., Academy, R., Trakt, S. S., Quinot, G., Liebenberg, S., Miller JC, I. I. I., Walton, T. F., ... Logan, J. (2014). 主観的健 康感を中心とした在宅高齢者における健康関 連指標に関する共分散構造分析

(Covariance structure analysis on healthrelated indexes in elderly at home with a focus on subjective health). Implementation Science, 39(1), 1-15. https://doi.org/10.4324/ 9781315853178

Salaswati, C. (2013). Pengetahuan dan Sikap Remaja Mengenai Pencegahan Penularan HIV/AIDS di SMU Negeri 2 Kota Dumai. In Fakultas Keperawatan, Universitas Sumatera Utara.

Salman Alfarisy, Agrina, \& Lestari, W. (2016). Efektifitas pendidikan kesehatan terhadap peningkatan pengetahuan remaja tentang dampak merokok. 1-9. https://www. neliti.com/publications/187620/efektifitaspendidikan-kesehatan-terhadap-peningkatanpengetahuan-remaja-tentang

Santoso, M. B., Apsari, N. C., \& Nabila, A. (2010). Upaya Pencegahan Hiv / Aids Pada Kalangan Remaja. Share : Social Work Journal.

UNAIDS. (2011). Global Report 2012 with Annexes. In MSF Access to Essential Medicines. papers2://publication/uuid/ 4467B415-2E9B-472A-89EFB30E692EFE5C

Visser, M. J. (2007). HIV / AIDS prevention through peer education and support in secondary schools in South Africa. 4(3), 678694. 